\title{
TRADE THROUGH THE DESERT: A LONG-TERM PERSPECTIVE ON GOODS, ANIMALS, AND POLITIES IN THE NEGEV ${ }^{1}$
}

\author{
COMERCIO A TRAVÉS DEL DESIERTO: UNA PERSPECTIVA A LARGO PLAZO \\ SOBRE LOS BIENES, ANIMALES, Y SOCIEDADES EN EL DESIERTO DEL NÉGUEV
}

\author{
Steven A Rosen ${ }^{2}$
}

Caravan trade in the Near East, and in the Negev, is the culmination of millennia of cumulative social and technological development, essentially an expression of complex economy societies with large-scale markets. The origins of caravan trade systems are to be sought in the specifics of their historical circumstances. For example, Nabatean trade developed in the wake of the rise of market demand in the Classical Mediterranean for such goods as spices, incense, etc., and in the specific geographic context of the Negev as land bridge between the Tropics and the Mediterranean. A longer-term view of desert trade traces the precursors of caravans back to earlier systems of exchange between the desert and settled zones. Such a perspective offers a cumulative view of the contexts and development of such trade systems, beginning as early as the Epipaleolithic, and evolving through the Neolithic, Chalcolithic, Bronze and Iron Ages. In this sense, the historically specific trade systems of such groups as the Nabateans fit into a larger set of longer term patterns, ever more complex in terms of diversity of goods, their social functions, distance of travel, technologies of transport, bulk of goods, social and economic frameworks for the trade, and infrastructure investment.

Key words: Caravans, donkeys, camels, Near East, exchange.

El comercio de caravanas en el Cercano Oriente, y en el desierto del Néguev, representa la culminación de milenios de desarrollo tecnológico y social acumulativo. Es, esencialmente, una expresión de sociedades con economía compleja y con mercados a gran escala. Los orígenes del sistema de comercio de caravanas se deben buscar en los detalles de sus circunstancias históricas. Por ejemplo, el comercio nabateo se desarrolló tras el aumento de la demanda del mercado en el Mediterráneo clásico para bienes tales como especias, incienso, entre otras, y en el contexto geográfico específico del desierto del Néguev como un puente terrestre entre los Trópicos y el Mediterráneo. Una mirada a más largo plazo del comercio en el desierto permite rastrear a los precursores de las caravanas hasta sistemas más tempranos de intercambio entre el desierto y las zonas habitadas. Tal perspectiva ofrece una visión acumulativa de los contextos y del desarrollo de tales sistemas de comercio, comenzando en el Epipaleolítico para luego evolucionar durante el Neolítico, Calcolítico, y las Edades de Bronce y Hierro. En este sentido, los sistemas de comercio históricamente específicos de grupos tales como los nabateos encajan en un conjunto más amplio de patrones de largo plazo, cada vez más complejos en términos de la biodiversidad de los bienes, sus funciones sociales, la distancia de viaje, las tecnologías de transporte, la cantidad de bienes, los marcos sociales y económicos para el comercio, y la inversión en infraestructura.

Palabras claves: caravanas, mulas, camellos, Cercano Oriente, intercambio.

\section{Caravans as an Endpoint in the Evolution of Desert Trade}

In the second half of the first millennium BCE a strategically located desert tribal group, the Nabateans (e.g. Graf 1990; Politis 2007), being in the right place at the right time, established control of the land route between the Red Sea and the Mediterranean (e.g., Meshel and Tsafrir 1975). In controlling this land route, they controlled a monopoly on the lucrative goods moving from the Tropics, South Arabia, the Horn of
Africa, and India, to the markets of the developing Roman world, goods that included spices, incense, cosmetics, perfumes, and medicinal herbs. The value of these goods was such that within the relatively short span of a few hundred years the Nabateans developed into a major state, covering much of the area of modern Jordan and the Israeli Negev. Looking at the Nabatean system today, with its caravanserais (e.g., Figure 1), the marked desert roads, the wells and cisterns established along the route, and of course, the capital city at Petra, we see what seems to be a prototypical caravan trade

\footnotetext{
${ }^{1}$ An earlier version of this article was presented at the International Workshop "Caravan Archaeologies: En Route to the Past, Present and Future”, Pica, Chile (May 2017). This manuscript was evaluated by external reviewers and edited by the Chungara Editorial Committee and the invited editors Persis B. Clarkson and Calogero M. Santoro.

${ }^{2}$ Archaeological Division, Ben-Gurion University of the Negev, POB 656 Beersheva 84105 Israel. rosen@bgu.ac.il
} 
system traversing the desert. If it is perhaps not the earliest of such systems in the Near East, it certainly marks an apogee in their development. Later caravan systems, such as those of the Ottomans, seem essentially similar, even if different in such details as the specifics of the trade and the technologies.

Nabatean trade developed in response to a specific set of historical circumstances. However, from a long- term perspective, the caravan trade is the culmination of earlier trade systems traversing the desert. These trade systems seem to originate as early as the Neolithic (and perhaps the preceding Late Epipaleolithic), with smallscale goods such as shells and green stones moving between the desert and the settled zone (e.g., Bar-Yosef Mayer 2005; Wright and Garrard 2003). They evolved concomitant with changing technologies, increasing

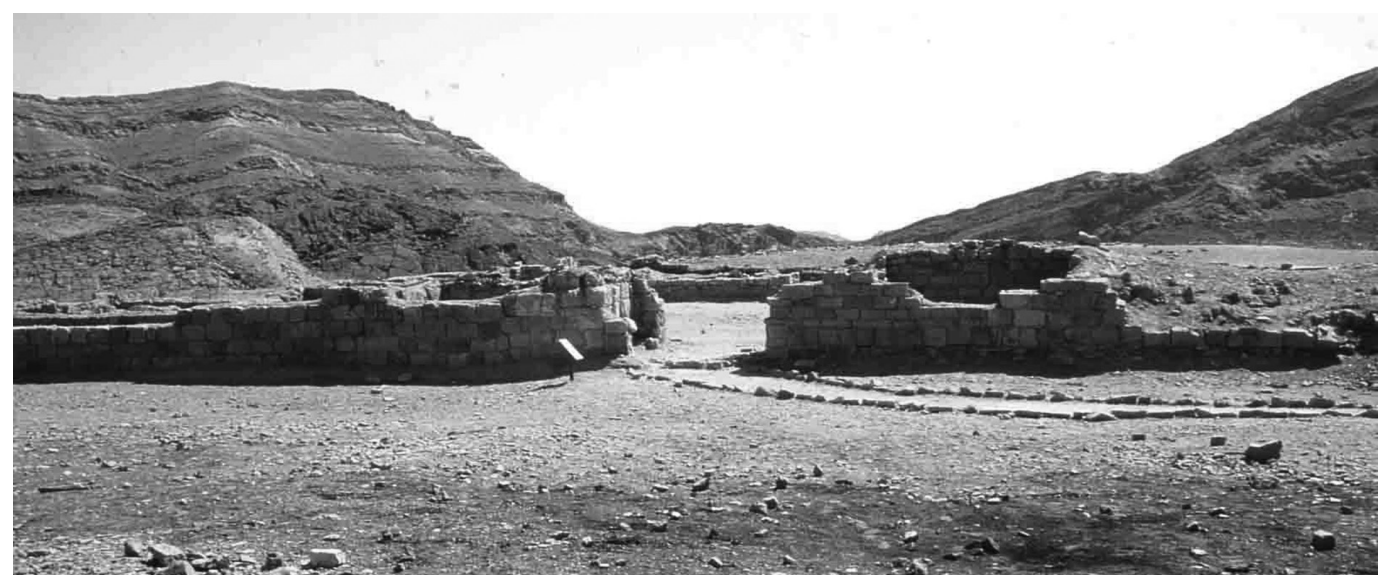

Figure 1. The Ein Saharonim (Sha'ar Ramon) Nabatean caravansary, located in the Central Negev.

El caravasar nabateo de Ein Saharonim (Sha'ar Ramon), ubicado en el Néguev Central.

social complexity both within the desert and beyond it, and ever-greater external market demand for the goods deriving from the desert or beyond it. Of course, this evolution was not linear, but subject to the vagaries of historical circumstance; thus, trade between the desert and the sown varied greatly in intensity and function from period to period, even if the long-term picture was one of increasing complexity (Table 1).

\section{The Southern Levantine deserts as a nexus of trade}

The deserts of the Southern Levant, including Sinai, the Negev, and southern and eastern Jordan (the Badia), form an arid ring around the fertile Mediterranean zone (Figure 2). Rainfall gradients to the south and east of the settled zone are steep. Within less than $100 \mathrm{~km}$ either east or south, rainfall drops to less than $100 \mathrm{~mm} /$ year and vegetation grades from Mediterranean forest and maquis to Irano-Turanian steppe and then to SaharoArabian desert (e.g., Danin 1983; Evenari et al. 1982:32; Garrard et al. 1988; Zohary 1953). Furthermore, rainfall in the deserts is restricted to the winter months, resulting in what might be called 'Mediterranean deserts'. There are no ameliorating summer rains. Environments are also affected greatly by local conditions, specifically topography, distance from the Mediterranean, and the presence of springs, both perennial and seasonal, resulting from larger scale geological structures. Thus, the central and southern Negev are impacted climatically by the Sinai coastline creating a pressure zone acting as a barrier to the deep penetration of the rain bearing winter Mediterranean cyclone systems. The rainfall gradient in the Negev and Sinai steepens as one moves south (Enzel et al. 2008). This, in turn, is ameliorated to a degree by the higher altitudes of the Central Negev and South Sinai, both showing penetrations of Irano-Turanian steppe. In South Sinai, occasional northerly incursions of monsoon rains may result in rare summer rainfall. The Rift Valley (Arava, Wadi Araba) is a deep graben surrounded by higher mountains in the west creating a rain shadow desert and extreme aridity. However, the graben itself results in substantial springs forming as aquifers meet the surface, and the steep mountains of southern Jordan in the east result in substantial run-off, both locally ameliorating the hyper-aridity of the Rift. In the Badia, the desert of eastern Jordan, springs and seasonal lakes are found in the Azraq Basin, and to a lesser degree in Jafr Basin, again, local ameliorations of arid and hyper-arid environments. 
Table 1. Absolute chronology chart with cultural sequences, general cultural development, sequence of animal uses, and types of trade.

Cronología absoluta de secuencias culturales, desarrollo cultural general, secuencia de usos de animales y tipos de comercio.

\begin{tabular}{|c|c|c|c|c|c|}
\hline $1000 \mathrm{CE}$ & $\begin{array}{l}\text { Middle } \\
\text { Ages }\end{array}$ & $\begin{array}{l}\text { Islamic } \\
\text { Byzantine }\end{array}$ & & & \\
\hline 0 & $\begin{array}{l}\text { Classical } \\
\text { Era }\end{array}$ & $\begin{array}{l}\text { Roman } \\
\text { Nabatean }\end{array}$ & $\begin{array}{l}\text { Imperial } \\
\text { Markets }\end{array}$ & $\begin{array}{l}\text { Camel } \\
\text { Caravans }\end{array}$ & $\begin{array}{l}\text { Long-Distance } \\
\text { Camel }\end{array}$ \\
\hline $1000 \mathrm{BCE}$ & Iron Age & & Early & $\begin{array}{l}\text { Camel } \\
\text { Introduction }\end{array}$ & $\begin{array}{l}\text { State-Based } \\
\text { Desert-to-Settled } \\
\text { Zone }\end{array}$ \\
\hline $2000 \mathrm{BCE}$ & $\begin{array}{l}\text { Mid/Late } \\
\text { Bronze } \\
\text { Age }\end{array}$ & Terminal & States & & \\
\hline $3000 \mathrm{BCE}$ & Early & Late & & $\begin{array}{l}\text { Donkey } \\
\text { Introduction/ } \\
\text { Domestication }\end{array}$ & $\begin{array}{l}\text { State Based } \\
\text { Desert-to-Settled } \\
\text { Zone } \\
\text { Trade }\end{array}$ \\
\hline $4000 \mathrm{BCE}$ & & $\begin{array}{l}\text { Timnian } \\
\text { Middle }\end{array}$ & $\begin{array}{l}\text { Mediterranean } \\
\text { Farming } \\
\text { Complex }\end{array}$ & $\begin{array}{l}\text { Copper } \\
\text { Smelting }\end{array}$ & \\
\hline $5000 \mathrm{BCE}$ & Pottery & Early & & Goat/Sheep & Desert-to-Settled \\
\hline $6000 \mathrm{BCE}$ & $\begin{array}{l}\text { Neolithic } \\
C\end{array}$ & Tuwailan & & $\begin{array}{l}\text { Introduced } \\
\text { To Desert }\end{array}$ & $\begin{array}{l}\text { Zone Agent Based } \\
\text { Exchange }\end{array}$ \\
\hline $7000 \mathrm{BCE}$ & $\begin{array}{l}\text { Pre-Pottery } \\
B\end{array}$ & & $\begin{array}{l}\text { Village } \\
\text { Farming }\end{array}$ & & \\
\hline $8000 \mathrm{BCE}$ & $A$ & & & Goat Domestication & $\begin{array}{l}\text { Reciprocal } \\
\text { Exchange }\end{array}$ \\
\hline \multicolumn{6}{|l|}{$9000 \mathrm{BCE}$} \\
\hline $10,000 \mathrm{BCE}$ & $\begin{array}{l}\text { Natufian } \\
\text { (Epi-Paleolithic) }\end{array}$ & & Hunting-Gathering & Gazelle, Ibex & \\
\hline $\begin{array}{l}\text { Calendric } \\
\text { Years }\end{array}$ & $\begin{array}{l}\text { General } \\
\text { Culture } \\
\text { Sequence }\end{array}$ & $\begin{array}{l}\text { Negev } \\
\text { Culture } \\
\text { Sequence }\end{array}$ & $\begin{array}{l}\text { Social System/ } \\
\text { Subsistence }\end{array}$ & $\begin{array}{l}\text { Animals in the } \\
\text { Desert }\end{array}$ & $\begin{array}{l}\text { Exchange } \\
\text { Structures }\end{array}$ \\
\hline
\end{tabular}

It is also important to acknowledge that modern environments, beginning with the impact of trends toward global warming which probably began some 200 years ago but which have accelerated in more recent times, cannot really serve as direct analogs for ancient times. Modern development, such as pumping water from aquifers as in the Azraq Basin, also impacts local environments (e.g., Baird et al. 1992; Garrard et al. 1988). This said, the regions under discussion may have fluctuated in their absolute degrees of aridity, but nevertheless have been essentially arid since the Early Holocene.

In the contexts of looking at the development of trade systems between the arid zone and the settled Mediterranean zone, the deserts functioned on two levels. At a regional level, resources deriving from the desert were traded into the settled zone from the earliest times. The geological and geographical variability in the region results in significant variation in resources and materials that might be transported from the desert zone, including copper, sea shells, ostrich eggshell for bead production, various minerals such as turquoise and stone materials such as Dabba marble, as well as goods like milling stones from basalt and sandstone deriving from the desert. In some periods, animals and animal products were also traded from the desert into the settled zone. At a supra-regional level, the Levantine deserts operated as land bridges between the Tropical Zone, meaning the Indian Ocean, India, South Arabia and the Horn of Africa, and the Mediterranean states and empires (Figures 2 and 3). Sinai, of course, operated as the land bridge between Egypt/Africa and the Near East, and the Badia as a link between Mesopotamia and the Levant, but these are not the focus of this essay. Thus, the deserts also were traversed, bringing goods and materials from other regions, to both the Levantine settled zone and beyond it, to the larger Mediterranean states and empires. The role of desert peoples at these two levels differs. Whereas at the regional level, the desert folk produced or mined goods and resources 
traded into the settled zone, at the supra-regional level they acted more as middlemen, in what may called transit trade. Notably, supra-regional trade did not of necessity displace the desert-settled trade, but rather eclipsed it in importance.

\section{Prehistoric exchange}

Over the course of almost two millennia, from ca. 8300 space to space $6700 \mathrm{BCE}$ space (the Levantine Pre-Pottery Neolithic B), full-fledged agricultural communities evolved in the Mediterranean zone. Basic characteristics of the Middle-to-Late PPNB included farming based on cereals (wheat and barley), legumes, fruit, and animal husbandry based on goats and perhaps sheep (e.g., Kuijt and Goring-Morris 2002). Over the course of the period, hunting, especially of gazelle, declined, replaced by domestic goat and sheep (e.g., Davis 1984; Garrard et al. 1996; Horwitz et al. 1999). Sites achieved sizes of up to 10 hectares of relatively dense occupation, especially in Transjordan, and two tiers of settlement size can be defined (e.g., Gebel
2004). Incipient craft specialization is reflected in some lithic technologies (e.g., Barzilai 2010), and other crafts and technologies included plaster production, woodworking, the manufacture of mud brick in molds, and even incipient ceramic production, to a degree belying the name of the period. Elaborate cult is evident in complex mortuary behavior (skull removal, plastering of skulls), ceramic statuary, and dedicated cult structures (e.g., Kuijt and Goring Morris 2002; Simmons 2007).

Beyond the Mediterranean zone, the societies of the desert regions continued to engage in mobile huntinggathering, organized in complex bands with sites rarely exceeding $1500 \mathrm{~m}^{2}$ in area. Research suggests seasonal migrations, often exploiting ecological differences between uplands and lowlands (e.g., Bar-Yosef and Bar-Yosef Mayer 2002; Goring-Morris 1993; Rosen 2017a:105-106; Simmons 1981). Notably, beyond fundamental contrasts in subsistence, architecture in the deserts reflects the mobile lifestyles, contrasting greatly with that of the Mediterranean zone, and the elaborate cult behavior and incipient economic complexity present in the settled zone is not evident in the desert.

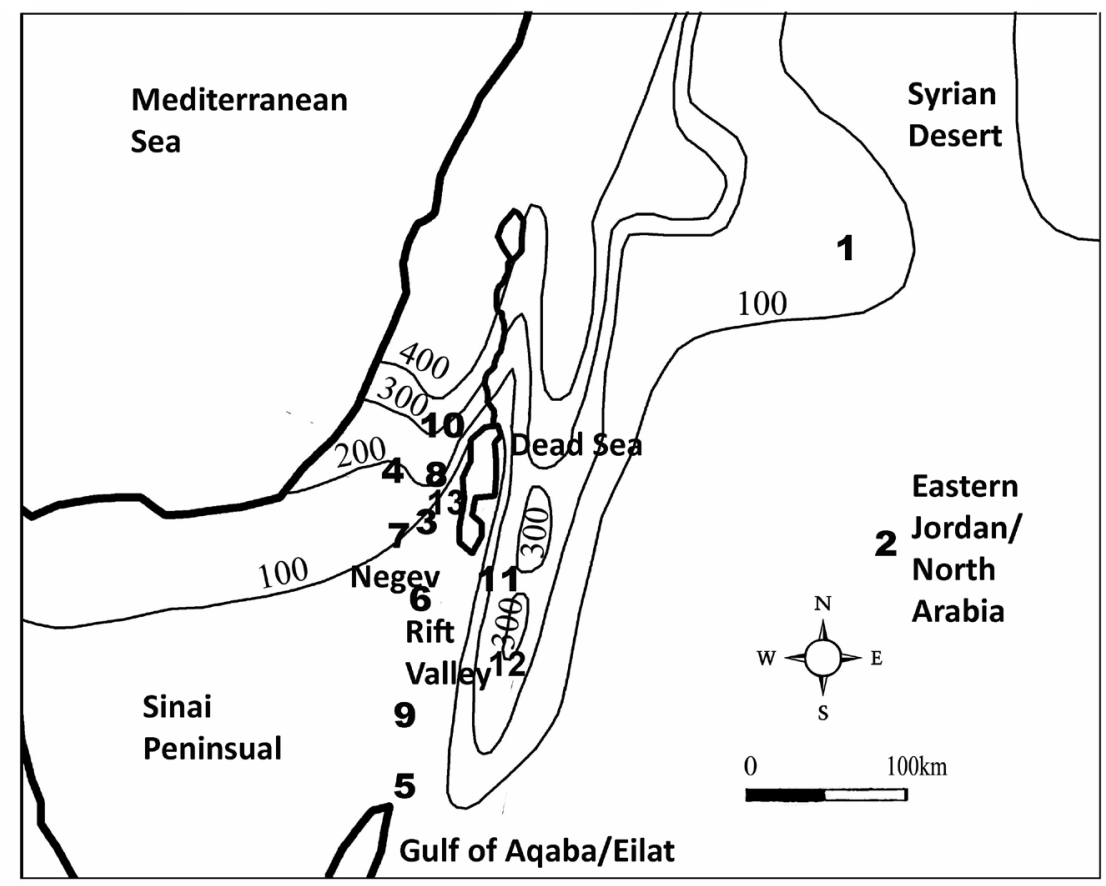

Figure 2. Map of region and rainfall isohyets, with sites and areas. (1) Azraq Basin, (2) Jafr Basin, (3) Nahal Tsafit, (4) Beersheva (Basin), (5) Tall al-Magass and Hujayrat al-Ghuzlan, (6) Ein Saharonim, (7) Beer Resisim/Ein Ziq, (8) Tell Masos, (9) Timna, (10) Judea, (11) Feinan, (12) Petra, (13) Nahal Mishmar (Cave of the Treasure).

Mapa de la región e isoyetas de precipitación, con sitios y áreas. (1) Azraq Basin, (2) Jafr Basin, (3) Nahal Tsafit, (4) Beersheva (Cuenca), (5) Tall al-Magass y Hujayrat al-Ghuzlan, (6) Ein Saharonim, (7) Beer Resisim/Ein Ziq, (8) Tell Masos, (9) Timna, (10) Judea, (11) Feinan, (12) Petra, (13) Nahal Mishmar (Cueva del Tesoro). 


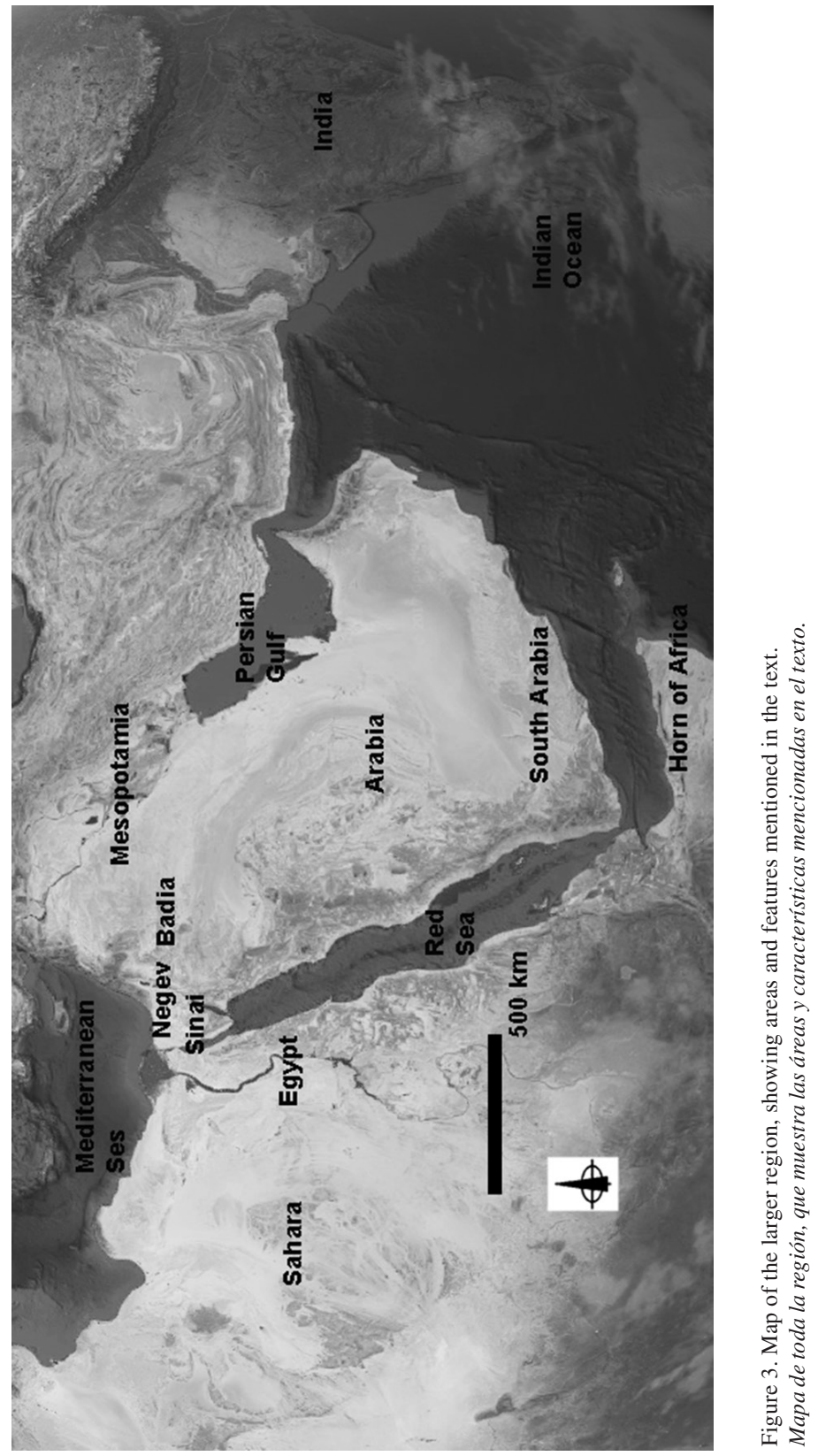


Goods deriving from the deserts and desert shores, the Red Sea, were transferred from the desert into the Mediterranean zone. These comprised essentially small-scale, non-bulk items, their mass limited by the absence of pack animals - they were carried by people. There is no evidence for complex trade systems based on human carriers, such as the Aztec pochteca (e.g., Berdan 2000). These goods included sea shells from the shores of the Red Sea, stone beads made on different minerals including greenstones found in the southern Negev, southern Jordan, and Sinai, other stones and minerals, such as Dabba Marble (apatite), originating in eastern Jordan (e.g., Bar-Yosef Mayer 2005; BarYosef Mayer and Porat 2008; Cooke 2013; Reese 1995; Wright and Garrard 2003). Overall, the function of these goods should be connected to identity at various levels, including status (Wright and Garrard 2003).

Given the likelihood that these goods were exchanged within the desert system, along with others that are not immediately evident as exchange goods, such as arrowheads, probably like-for-like (e.g., Wiessner 1983), the internal desert system should best be classified as one of reciprocal exchange. Several media can be suggested for such exchanges, including meetings between hunting sub-bands (e.g., Bar-Yosef and Belfer-Cohen 1989), meetings between bands as part of seasonal aggregation during yearly cycles of migration, and down-the-line exchange systems (e.g., Cann and Renfrew 1964; Fry 1980) based on one or the other of the above. However, beyond exchange within the desert, the trade that developed between the PPNB farming villages and the hunter-gatherer bands, fundamentally economically disparate societies, should be not classified as simple reciprocity (Rosen 2017a:123-124). Based primarily on ethnographic analogy and in the absence of markets in these early periods, it is difficult not to see here the presence of informal agents acting as the loci of exchange between the hunter-gatherer groups and their sedentary neighbors. Furthermore, if the primary goods imported from the desert to the settled zone in this period were status and identity based, it is not clear at all that those exported to the desert were functionally similar. Thus, sea shells from the Mediterranean are absent from South Sinai PPNB assemblages, although Red Sea shells are present in the Mediterranean zone (BarYosef Mayer 2005). Based primarily on ethnographic analogy with modern Bedouin exchange systems, but also on the presence of milling stones in most PPNB sites, Bar-Yosef Mayer and Bar-Yosef (2002) suggest that grain was imported from the farming zones into the desert, supplementing gathering. Somewhat later, it is clear that cotton (Betts et al. 1994) and linen (Shamir and Rosen 2015) textiles were imported into the desert from the settled zone and given the antiquity of linen, it is not unreasonable to assume that it was among the exchange goods received by desert peoples very early on. In the absence of organic materials, it is difficult to speculate further, but the asymmetries of trade between the desert and settled zones seen as early as the PrePottery Neolithic serve as the basis for the development of later trade systems.

\section{Protohistoric exchange and the development of desert trade}

Goats were adopted into the Levantine deserthuntergatherer societies beginning in the PPNC (ca. 6700$6200 \mathrm{BCE}$ ), corresponding to the period of collapse of the PPNB village system in the sedentary zone. The rise of goat and sheep herding in the desert, characterized in this early period as herding-gathering (Gilbert 1983; Rosen 2017a:110-130), and the transition from hunting to herding as a primary subsistence mode, had major implications for social organization, culminating in the evolution of tribal societies (Parkinson 2002; Rosen 2017a for definitions and discussions of tribes).

Although the PPNB collapse must have caused disruptions in the desert-settled exchange systems, and the adoption of herding changed the basic structures of desert society, based on the archaeology it is difficult to trace any change in the basic character of exchange between the desert and the settled zone until the end of the 5th millennium BCE. In addition to the goods described for the PPNB, during the Tuwailan culture/ period (the desert equivalent to the PPNC) large flake tools (bifacial knives, tile knives, and later in the sequence, tabular scrapers), at least partially attached to ritual functions, were traded from quarries and workshops in the desert into Late Neolithic village society (Goring-Morris et al. 1994; Rosen 2017a:122). In Jordan, the large size of some of these quarries has led some researchers to suggest an industrial scale to this exchange (e.g., Abe 2008; Müller-Neuhof 2013; Quintero et al. 2002), although the date of these quarries has not been well established and probably well postdates the PPNC. However, the intensity of this exchange is difficult to gauge given problems of chronology and the classic issue of whether density of materials reflects short-term intensity of exploitation or long term accumulation. In the Negev, the extensive (as opposed to intensive) nature of production of these tools is clear, based upon the small scale of quarry/production sites (e.g., Rosen 2017a:164, footnote p.166). Regardless, all agree that desert pastoral peoples were involved in systematic trade of these large flake tools from the arid periphery into the settled zone.

In this context, it is important to note that there is no evidence for the harnessing of animals in the desert prior to the domestication of the donkey. The use of the 
travois, pulled by dogs or people, is unknown. There are iconographic hints that goats may have occasionally served as pack animals, as in the ceramic figurine of the Gilat Ram (Israeli and Tadmor 1986:fig. 17), but even accepting this doubtful possibility, goats as pack animals are fundamentally limited.

The seeds of major change were sown in the late 5th millennium BCE, in the Chalcolithic period, with the beginnings of copper metallurgy. Ore sources are found exclusively in the desert zones at Feinan in the Rift Valley in Jordan, at Timna, farther south in the Rift Valley, and in South Sinai (e.g., Adams 2002; Golden 2010; Rothenberg and Glass 1992). Although direct evidence for Chalcolithic copper mining/production has not been found in Feinan, chemical analyses strongly suggest that it was the primary source for most of the copper found in the Mediterranean heartland of the Ghassulian culture (Hauptman 2007; Shugar 2001). Hundreds of copper objects, the vast majority cultic in function, have been recovered from Chalcolithic sites in the Ghassulian realm, most especially notably the hoard of objects from the Nahal Mishmar cave (Bar-Adon 1980). Levy (2007) has suggested that organized donkey caravans brought ores from Feinan to the Beersheva Basin, where there is evidence for copper smelting (e.g., ; Gilead et al. 1992: Levy and Shalev 1989; Shugar 2001). There are disputes over the date of the domestication of the donkey and its systematic integration into trade economies, with many researchers suggesting significantly later date for domestication (e.g., Milevski 2013). However, beyond this, recent excavations at the site of Nahal Tsafit, an encampment on the road from Feinan to the Beersheva basin and the Chalcolithic heartland, suggest that copper was traded into the settled zone by desert pastoralists (Knabb et al. 2018.; also Gates 1992 for pastoral involvement in trade). Although dated to the late 5th and early 4th millennia BCE, contemporary with the Ghassulian culture, Nahal Tsafit represents a characteristic site of the desert Timnian culture, with material assemblages, architecture, and a geographical distribution quite different from that of its northern contemporary. Petrographic analysis of the ceramics from the site indicates sources both in Feinan and in Judea, thus reflecting Timnian trade connections and perhaps even movement. The presence of ceramic cores originating in the settled zone in some Chalcolithic objects suggests that at least some of the actual manufacture also took place away from the copper sources, suggesting export of ores rather than finished items. The presence of arsenical/antimony/copper alloys, whose sources appear to be in Armenia, indicates long-range trade for some of the objects, although the structure of this trade has been difficult to investigate.

Entrepôts for the copper trade, apparently connected to Egypt, also were established in the Aqaba area, at the sites of Tall al-Magass and Hujayrat al-Ghuzlan (Khalil and Schmidt 2009), dating to the terminal $5^{\text {th }}$ and earlymid $4^{\text {th }}$ millennia BCE. Both the copper and the ceramic typologies suggest connections to Feinan (Kerner 2009). The presence of casting molds and ingots suggests on-site production. The connections to desert peoples is evident in elements of the material culture at the sites, although the sites themselves are dense concentrations of rectilinear construction with proper stone walls and deep stratigraphy, indicating intensive occupation, in great contrast to the typical desert Timnian campsites. It is tempting to conclude that the copper trade between Feinan and the Red Sea was based on donkey caravans given the presence of donkey bones at Hujayrat al-Ghuzlan. However, the issue is not clear, and the chronology of the evolution of this trade is still unresolved.

Other desert goods traded into the settled zone continue to include various types of shells, shell beads (Bar-Yosef Mayer 2005) and beads of other materials (e.g., van den Brink et al. 2004), granite objects (e.g., violin shaped figurines [Oren and Gilead 1981]), hematite (Knabb et al. 2018), and tabular scrapers (large flake tools) (Abe 2008; Fujii 2011; Rosen 1983). As with the preceding phase, if on the one hand this trade was not intensive, but neither was it merely the reciprocal exchange of gifts evident in within the desert system. As in the preceding periods, it must have required agents and formalized structures of exchange. However, beyond this, the Timnian culture in this period (the Middle Timnian) remained essentially autonomous. Exchange with the settled zone was a supplement to the pastoral economy, not a mainstay.

\section{The donkey and the Bronze Age}

The domestication of the donkey and its integration into Levantine trade economies changed the nature of desert exchange systems. There is debate concerning the actual date of the domestication of the donkey and the status of equid remains at Chalcolithic sites in the southern Levant (e.g., Grigson 2012; Milevksi 2013; Ovadia 1992; Rossel et al. 2008). However, certainly over the course of the $4^{\text {th }}$ millennium BCE, the role of donkeys in desert-sown trade becomes evident in both the increase in numbers of objects traded and in the mass of individual objects. If in the Chalcolithic period (late $5^{\text {th }}$ millennium BCE) we can see the import of basalt bowls, sometimes 10s of kilograms in mass (e.g., Gilead and Goren 1989; Rowan 1998), into the Beersheva Basin from distances of perhaps $100 \mathrm{~km}$ or more, from sources in southern Jordan, the numbers of these bowls seems limited. In comparison, for example, in northern Israel, the Natufians also imported large basalt vessels from distances up to $50 \mathrm{~km}$ (WeinsteinEvron et al. 1999), obviously well before the domestication of the donkey. However, by the late 4th or early 3rd millennium BCE, hundreds of ferruginous and 
quartzitic sandstone milling stones were imported into the town of Arad from the Central Negev, of similar mass and similar distances to the basalt vessels, a trade in mass which seemingly must have necessitated the use of donkeys. The presence of donkey bones at Hujayrat al-Ghuzlan and the possible connection to the early copper trade has already been indicated. Furthermore, Abe (2008) and Müller-Neuhoff (2013) suggest that the tabular scraper trade, from the desert quarry workshops to the settled sites of the Mediterranean zone, apparently during the same period (although dating is difficult) was facilitated by donkey transport. On the other hand, some of this trade may perhaps be attributed to pastoral exchange systems rather than formal caravan systems.

Thus, it is difficult to determine with any certainty when formal (or for that matter, informal) donkey caravans were first integrated into the desert-settled trade economies. Certainly, by the mid- $3^{\text {rd }}$ millennium in Mesopotamia, donkey caravans were well-established, as indicated in texts (e.g., Wayne and Violet 2012); however, Mesopotamian donkey caravans appear to travel between towns and cities within the settled zone, rather than traversing the desert. We may suggest donkey caravans between Feinan and the towns of the southern Levant in the Early Bronze Age. If copper objects in Ghassulian habitation sites $\left(5^{\text {th }}\right.$ millennium BCE) in the Southern Levant should be characterized as rare (and not really requiring such organized transport), at the Early Bronze Age II town of Arad (early $3^{\text {rd }}$ millennium BCE) they numbered hundreds of objects, including more than 50 copper axes, essentially an ax to each household (Ilan and Sebbane 1989). Furthermore, the scale of copper production at Feinan (the primary source for Aradian copper) in the $3^{\text {rd }}$ millennium BCE, the Early Bronze II/III, was orders of magnitude greater than in the preceding periods, thus perhaps indeed suggesting donkey caravans as the medium of transport for copper objects. A key aspect of this transition is the shift from trade/transport of rare objects to everyday objects, that is, mass or bulk trade. Similarly, the movement of large pots, cooking ware and storage jars, between the Negev/Sinai and the settled zone in the early $3^{\text {rd }}$ millennium (e.g., Amiran et al. 1973), at least sometimes associated with outposts attached to the copper trade, almost certainly required donkey transport. The contrast between these outposts and typical pastoral encampments (e.g., BeitArieh 1986; Saidel 2002) suggests a form of directed trade and should probably be characterized as an early type of caravan trade. Toward the end of the third millennium BCE, after the collapse of the Early Bronze Age urban system in the north of the country, the Negev in the Intermediate Bronze Age (=EBIV, EBMB, MB1, etc.) saw a florescence in habitation sites, some achieving sizes of 100 or 200 structures (Cohen
1999). Connections with Feinan would have been well established, both based on ceramic petrography and the discovery of caches of copper ingots at a number of sites (Goren 1996; Segal and Roman 1999). The copper trade continued, probably on to Egypt (e.g., Goren 1996), despite the collapse of the Levantine urban matrix, and the intensity of exploitation of copper during this period as evident in various sites in the Arava (Yekutieli et al. 2005) again suggests the possibility of donkey caravans. Schwimmer (2016) has recently conducted a survey of rock art in the region between the two major Intermediate Bronze Age sites of Ein Ziq and Beer Resisim and combining GIS analysis of optimal routes and the location of specific elements of the rock art associated specifically with Intermediate Bronze Age material culture. He suggests a partial route for a donkey-copper trade system ultimately connecting Feinan with Egypt, but passing through the central Negev.

Evidence for agricultural practices associated with Intermediate Bronze Age sites in the central Negev is absent (no sickle segments, no associated fields or threshing floors, etc.). Combined with the large size of some of these sites, there was perhaps a need for regular provisioning, again suggesting the possibility of organized donkey caravans, although one cannot rule out simpler pastoral exchange systems.

In the succeeding periods, the Middle and Late Bronze Ages, there is scarce evidence for habitation sites in the central Negev. There are disputes over the meaning of the virtual absence of archaeological sites in the region (in great contrast to preceding and succeeding periods) (e.g., Finkelstein and Perevoletsky; 1990; Rosen 1987, 2017b), but in the absence of evidence, one can certainly not reconstruct desert trade systems, or even posit their existence.

\section{The camel and Iron Age trade}

The adoption of the domestic dromedary (e.g., Bulliet 1990; Kohler-Rollefson 1996; Rosen and Saidel 2010; Sapir-Hen and Ben-Yosef 2013; Wapnish 1981; Zarins 1978 for reviews of camel domestication and exploitation) into the economic systems of the Near Eastern deserts impacted every aspect of desert life. The camel is stronger and larger than the donkey, and is able to penetrate more deeply into the desert. Thus, a donkey can carry on the order of $80 \mathrm{~kg}$ and is best watered every day (e.g., Ngendello and Heemskerk 2004). A male camel can be loaded with 200-300 km and can travel up to three days without being watered (Gauthier-Pilters and Dagg 1981). Neither horses nor oxen can be used as effectively as camels in the desert. Of course, wheeled vehicles enhance transport efficiency, but require road infrastructures, maintenance, and equipment. 
Bulliet (1990) made the case long ago for the superior efficiency of pack camels in desert environments.

Finkelstein (1988) has attached the Iron Age florescence in the Central Negev to the domestication of the dromedary, suggesting that it coincided with specific political contexts, the rise of Iron Age states, which enabled significant increase in Arabian trade, and consequent economic prosperity in the Negev, especially as concerning the site of Tell Masos (also Fritz 1981; Kempinksi 1978). Much of his argument is based on analogy with the late 1st millennium Nabatean trade system, but the actual content of the proposed increase in trade, what goods were transported and traded, is not examined. In contrast, Sapir-Hen and Ben-Yosef (2013), and Grigson (2012) also see the camel playing a crucial role in the development of trade out of Timna in this period, clearly to be associated with copper. A similar case can be made for Feinan, achieving a peak in intensity of copper production in this period (Hauptmann 2007; Levy et al. 2012), and presumably facilitated by the use of camels. One can posit an already extant donkey caravan trade between these different areas of the desert, such as Red Sea ports like Etzion Geber = Tell el-Kheleifeh (e.g., Pratico 1985), and other resource exploitation sites like Timna or Feinan and the settled Mediterranean zone. If so, then with respect to this trade, the introduction of the domestic camel is primarily an increase in efficiency of trade, again, the primary factor being bulk and mass. Notably, however, service sites (caravanserais, watering stations, guard towers, etc.) along obvious routes and ways are not evident in the Iron Age. If the Iron Age forts of the central Negev (e.g., Figure 4) somehow served some of these functions (equipped with cisterns, enclosed areas, rooms, and fortified), then the routes are certainly not clear and suggest that use as trade/way stations was not the only primary function of these sites, if indeed a primary function at all; they may have served as small military or police outposts, perhaps providing sanctuary during raids or other disturbances.

\section{The Nabatean spice route}

In the Negev, the Nabatean Spice Route, leading from the Red Sea to Petra and across the Negev to the Mediterranean Sea (e.g., Cohen 1982; Evenari et al. 1982:32; Meshel and Tsafrir 1975), is the first caravan route to show clearly the infrastructures we associate with caravan trade, way-stations (caravanserais), watch-towers, road markers, and cisterns not directly associated with habitations. The spacing of the Nabatean caravanserais through the Negev, roughly 15-20 km between stations, suggests a day's journey. The caravanserais themselves are equipped with

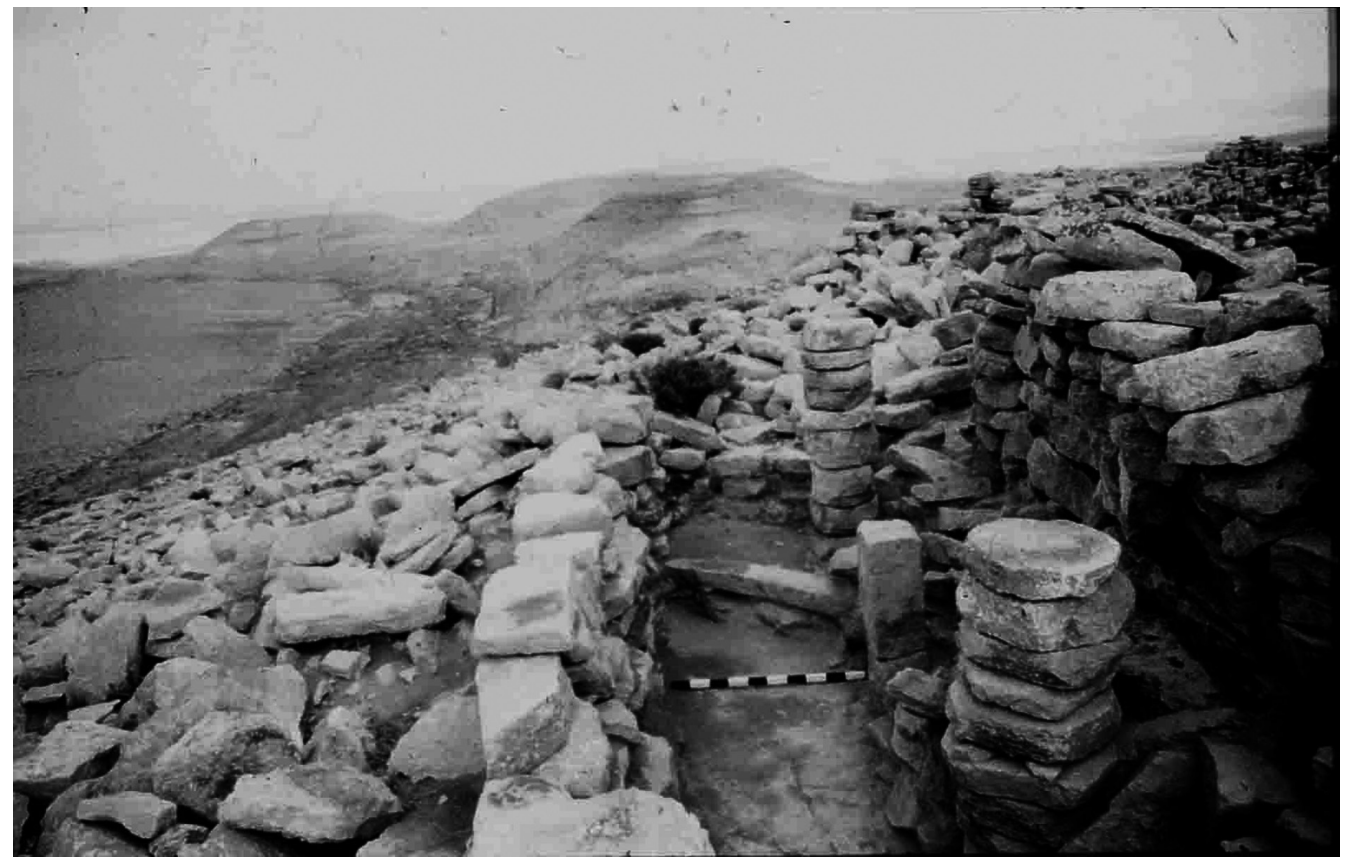

Figure 4. Casemate wall of Iron Age hill fort of Nahal Akrav, Central Negev.

Muro de casamata de un castro de la Edad de Hierro de Nahal Akrav, Néguev Central. 
rooms, open courtyards, large kitchens, and water, and suggest a defensive stance, if not truly fortified. There are no texts describing the actual daily function of the way stations, but based on the large investments evident, the standardized formats, and the texts describing Nabatean military in the general region, most scholars assume they were state administered (e.g., Caner 2010:6-7; Cohen 1982; Meshel and Tsafrir 1975). The key difference between the Nabatean caravan trade and preceding trade systems, whether incorporating caravans or not, is the clear evidence for state investment in support infrastructure along the extent of the trade route.

The goods transported included spices, perfumes, medicinal herbs, incense, and cosmetics, all originating in the Tropics, in south Arabia, the Horn of Africa, and India (e.g., Amar 2003). All qualify as luxury goods, valuable and thus economically justifying the long distance and efforts of transport. Notably, the trans-desert segment of the passage was only part of a longer route that included significant sea travel, but the relatively short overland trip from the Red Sea to the Mediterranean was clearly lucrative, as evidenced in the accumulated wealth of the Nabatean kingdom. Once the trade-winds crossing the Red Sea were understood (Crone 1987), the Nabatean trade system (already annexed by Rome in $106 \mathrm{CE}$ ) was effectively eclipsed and the primary trade route shifted to the shores of Egypt, transport across the Eastern Desert, and shipment down the Nile.

\section{Evolutions of trade}

The sequence presented above is, of course, historically particular. However, the themes and methods reflected in this Negev sequence are universal. These can be examined from the perspectives of the changing functions of the goods traded from the desert to the settled zone over time, the changing technologies and infrastructures of trade, and, as a kind of umbrella overview, changing social, political, and economic contexts of trade.

In terms of goods traded (again, from the desert to the settled zone), the sequence is as follows (Table 1): (1) In the Epipaleolithic and Neolithic periods, the goods traded comprise exclusively small scale identity markers, most notably shells and beads. On one level, such goods would seem to suggest a form of reciprocity. On another, the disparities between the zones, with village systems (in the Neolithic, but perhaps as early as the Natufian) and the hunter-gatherer bands of the desert, would suggest more formal economic structures, agents of one kind or another acting as intermediaries, to mediate the social asymmetries of the trade.
(2) Culminating in the Early Bronze Age (Late Timnian in the desert), but from earlier beginnings in the Chalcolithic Period (Middle Timnian), goods reflect new functions, most notably significant utilitarian aspects (milling stones, stone vessels), and corporate cult functions (especially in the copper objects of the Chalcolithic period). In fact, we still do not know in what form copper was traded from the desert to the settled zone, but regardless, trade in the late $5^{\text {th }}$ through $3^{\text {rd }}$ millennia BCE transcended simple identity. If we posit some kind of agent-based exchange for the earlier periods, then most certainly by the $3^{\text {rd }}$ millennium $\mathrm{BCE}$ we can posit some variability in trade functions, probably including formal trade agents at trading posts and in settlements, itinerant traders, and markets in the central settlements themselves. This trade is clearly predicated on the domestication of pack animals, donkeys, capable of transporting both massive and bulky goods.

(3) With the domestication of the camel, concomitant with the rise of Iron Age states and empires, the capacity of trade increased, both in terms of quantity and distance, and with it the range of goods and related social functions. In particular, this should probably be associated with the increasing intensity of copper exploitation, a result of the rise of state level distributive mechanisms and the greater range of goods that are associated with the use of tin bronze, including metal tools and weapons.

(4) The rise of the first millennium empires of the Near East and Mediterranean established large scale markets, resulting in new trade systems and adding an entire new set of luxury items from the tropics to be integrated into growing elite systems. Thus, the basic set of Nabatean goods fed into cult systems as in vast amounts of incense used in both pagan and Jewish/Christian ritual throughout the Mediterranean region and status markers (as in the cosmetics and perfumes part of the trade system) to distinguish from the corporate identity markers of earlier periods, with new goods and on scales not previously seen.

These changes are, of course, correlated with changing technologies and ever-increasing infrastructure investment, in turn concomitant with ever-increasing socio-economic complexity and everlarger demographic pools. Thus, technologies like the introduction of the North Arabian saddle (Bulliet 1990), allowing more effective warfare from camel back, were innovations tied inextricably to the evolving sedentary societies, but with great impacts on desert societies as well (in this case, among other things, increased military threats to the settled zone). Indeed, even the introduction of various domestic pack animals can be viewed as technological innovations, but innovations which occurred elsewhere and were adopted into 
the desert, thus again reflecting the fundamental connections between social, political, economic, and technological changes.

It is, of course, trivial to conclude that the development of trade is a function of evolving societies; however, the evolutions reviewed here are not linear, but marked by the instabilities of ancient urban civilization (e.g., Marcus 1998) tempered by desert adaptations. That is, there is a particularism associated with the evolution of southern Levantine desert trade systems with periods of evolving trade and periods of little or no trade. Beyond such specific examples as the Red Sea trade winds mentioned above, or periods of the political expansion of the Mediterranean states into the Levantine deserts, these periods match the dynamics of desert demography (Rosen 2017b), with periods of demographic expansion versus contraction. During periods of contraction, desert trade, in all its functions and diversity, also contracted. In this context, it is also worth noting that the set of functions, technologies, and range of goods evident in the sequence was cumulative. Each period of trade florescence added to the previous period of florescence, not constrained by the immediately preceding period of contraction. This phenomenon of cumulative functions is clearly the result of social continuities beyond the desert itself and is again reflective of the varying degrees of integration between the desert and the settled regions over time.

Acknowledgments: I am grateful to Persis Clarkson and Calogero Santoro for inviting me to participate in the Caravans Workshop. Lior Schwimmer graciously allowed me to cite his as yet unpublished work on rock art and trade routes. I am grateful to two reviewers for their valuable comments, genuinely improving the quality and usefulness of the paper.

\section{References Cited}

Abe, M. 2008. The Development of Urbanism and Pastoral Nomads in the Southern Levant - Chalcolithic and Early Bronze Age Stone Tool Production Industries and Flint Mines in the Jafr Basin, Southern Jordan. Unpublished doctoral dissertation, University of Liverpool, Liverpool.

Adams, R.B. 2002. From farms to factories: the development of copper production at Faynan, Southern Jordan, during the Early Bronze Age. In Metals and Society, edited by B.S. Ottaway and E.C. Wager pp. 21-32. British Archaeological Reports International 1061, BAR, Oxford.

Amar, Z. 2003. The ancient trade in incense, perfumes and spices. Michmanin 25:61-66.

Amiran, R., I. Beit-Arieh and J. Glass 1973. The interrelationship between Arad and sites in the southern Sinai in the Early Bronze II. Israel Exploration Journal 23:33-38.

Baird, D., A. Garrard, L. Martin, and R. Wright 1992. Prehistoric environment and settlement in the Azraq Basin: an interim report on the 1989 excavation season. Levant 24:1-31.

Bar-Adon. P. 1980. The Cave of the Treasure. Israel Exploration Society, Jerusalem.

Bar-Yosef, O. and D.E. Bar-Yosef Mayer 2002. Early Neolithic tribes in the Levant. In The Archaeology of Tribal Societies, edited by W.A. Parkinson, pp. 340-371. International Monographs in Prehistory 15, Ann Arbor.

Bar-Yosef, O. and A. Belfer-Cohen 1989. The PPNB interaction sphere. In People and Cultures in Change, edited by I. Hershkowitz, pp. 59-72. British Archaeological Reports International 508. BAR, Oxford.

Bar-Yosef Mayer, D.E. 2005. The exploitation of shells as beads in the Paleolithic and Neolithic of the Levant. Paléorient 31:176-185.

Bar-Yosef Mayer, D.E. and N. Porat 2008. Green stone beads at the dawn of agriculture. Proceedings of the National Academy of Sciences 105:8548-8551.
Beit-Arieh, I. 1986. Two cultures in South Sinai in the Third Millennium B.C. Bulletin of the American Schools of Oriental Research 263:27-54.

Barzilai, O. 2010. Social Complexity in the Southern Levantine PPNB as Reflected through Lithic Studies: The Bidirectional Blade Industries. Archaeopress, Oxford.

Berdan, F.F. 1988. Principles of regional and long-distance trade in the Aztec empire.In Smoke and Mist: Mesoamerican Studies in Memory of Thelma D. Sullivan, edited by J. Kathryn Josser and Karen Dakin, pp. 639-656. British Archaeological Reports International Series 402. BAR, Oxford.

Betts, A.V.G., K. Van Der Borg, A. De Jong, C. Mcclintock, and M. Van Stryndonk 1994. Early cotton in North Arabia. Journal of Archaeological Science 21:489-500.

Bulliet, R. 1990. The Camel and the Wheel. Columbia Univ. Press, New York.

Caner, D.F. 2010. History and Hagiography from the Late Antique Sinai. Liverpool University Press, Liverpool.

Cann, J.R. and C. Renfrew 1964. The characterization of obsidian and its application to the Mediterranean region. Proceedings of the Prehistoric Society 30:111133.

Cohen, R. 1982. New light on the date of the Petra-Gaza Road. Biblical Archaeologist 45:240-247.

Cohen, R. 1999. Early Settlement in the Negev Highlands. Israel Antiquities Reports 6. Israel Antiquities, Jerusalem. (Hebrew).

Cooke, L. 2013. Bead working. In The Later Prehistory of the Badia. Excavations and Surveys in Eastern Jordan, edited by A.V.G. Betts, D. Cropper, L. Martin and C. McCartney, pp. 26-30. Levant Supplementary Series 11. Council for British Archaeology in the Levant, Oxbow, Oxford.

Crone, P. 1987. Meccan Trade and the Rise of Islam. Princeton University Press, Princeton. 
Danin, A. 1983. Desert Vegetation of Israel and Sinai. Cana, Jerusalem.

Davis, S. 1984. Climatic change and the advent of domestication: The succession of ruminant Artiodactyls in the Late Pleistocene - Holocene in the Israel Region. Paléorient 8:5-15.

Enzel, Y., R. Amit, U. Dayan, O. Crouvi, R. Kahana, B. Ziv, and D. Sharon 2008. The climatic and physiographic controls of the eastern Mediterranean over the Late Pleistocene climates in the Southern Levant and its neighboring deserts. Global and Planetary Change 60:165-192.

Erickson-Gini, T. and Y. Israel 2013. Excavating the Nabataean incense road. Journal of Eastern Mediterranean Archaeology and Heritage Studies 1:24-53.

Evenari, M., L. Shanan, and N. Tadmor 1982. The Negev: The Challenge of a Desert. Harvard University Press, Cambridge.

Finkelstein, I. and A. Perevoletsky 1990. Processes of Sedentarization and Nomadization in the History of the Negev and Sinai. Bulletin of the American Schools of Oriental Research 279:67-88.

Finkelstein, I. 1988. Arabian trade and socio-political conditions in the Negev in the twelfth-eleventh centuries BCE. Journal of Near Eastern Studies 47:241-252.

Fritz, V. 1981. The Israelite "conquest" in light of recent excavations at Khirbet el Meshâsh. Bulletin of the American Schools of Oriental Research 241:61-73.

Fry, R.E. 1980. Models of exchange for major shape classes of lowland Maya pottery. In Models and Methods in Regional Exchange, edited by R.E. Fry, pp. 3-18. Society for American Archaeology Papers No. 1. SAA, Washington D.C.

Fujii, S. 2011. 'Lost Property' at Wadi Qusayr 173: Evidence for the transportation of tabular scrapers in the Jafr Basin, southern Jordan. Levant 43:1-14

Garrard, A., S. Colledge, and L. Martin 1996. The emergence of crop cultivation and caprine herding in the "marginal zones" of the Southern Levant. In The Origins and Spread of Agriculture and Pastoralism in Eurasia, edited by D.R. Harris, pp. 204-226. Smithsonian Institution Press, Washington D.C.

Garrard, A. N., C. Hunt, R. Montague, and S. Colledge 1988. Environment and subsistence during the Late Pleistocene and Early Holocene in the Azraq Basin. Paléorient 14:40-49.

Gates, M.H. 1992. Nomadic pastoralists and the Chalcolithic hoard from Nahal Mishmar. Levant 24:131-139.

Gauthier-Pilters, H. and A.I. Dagg 1981. The Camel, Its Evolution, Ecology, Behavior, and Relationship to Man. University of Chicago Press, Chicago.

Gebel, H.G.K. 2004. Central to what? The centrality issue of the LPPNB mega-site phenomenon in Jordan. In Central Settlements in Neolithic Jordan, edited by H.D. Biemert, H.D.K. Gebel, and R. Neef, pp. 1-19. Studies in Early Near Eastern Production, Subsistence and Environment 5. Ex Orient, Berlin

Gilbert, A.S. 1983. On the origins of specialized nomadic pastoralism in Western Iran. World Archaeology 15:104-119.

Gilead, I. and Y. Goren 1989. Petrographic analyses of fourth millennium B.C. pottery and stone vessels from the Northern Negev, Israel. Bulletin of the American Schools of Oriental Research 275:5-14.
Gilead, I., S.A. Rosen, P. Fabia, and B. Rothenberg 1992. New archaeo-metallurgical evidence for the beginnings of metallurgy in the southern Levant. Excavations at Tell Abu Matar, Beersheva (Israel) 1990/1. Bulletin of the Institute for Archaeo-Metallurgical Studies 18:11-14.

Golden, J. 2010. Dawn of the Metal Age: Technology and Society during the Levantine Chalcolithic. Equinox, London.

Goren, Y. 1996. The Southern Levant in the Early Bronze Age IV: the petrographic perspective. Bulletin of the American Schools for Oriental Research 303: 33-72.

Goring-Morris, A.N. 1993. From foraging to herding in the Negev and Sinai: the Early to Late Neolithic transition. Paléorient 19 (1):65-89.

Goring-Morris, A. N., A. Gopher, and S.A. Rosen 1994. The Tuwailan cortical knife industry of the Negev, Israel. In Neolithic Chipped Stone Industries of the Fertile Crescent, edited by H.G. Gebel and S.K. Kozlowski, pp. 511-524. Studies in Early Near Eastern Production, Subsistence, and Environment I. Ex Oriente, Berlin.

Graf, D.F. 1990. The origins of the Nabateans. ARAM 2:45-75.

Grigson, C. 2012. Size matters - donkeys and horses in the prehistory of the southernmost Levant. Paléorient 38:185-201.

Grigson, C. 2012. Camels, copper and donkeys in the Early Iron Age of the Southern Levant: Timna Revisited. Levant 44:82-100.

Hauptmann, A. 2007. The Archaeo-metallurgy of Copper: Evidence from Faynan, Jordan. Springer, Berlin.

Horwitz, L.K., E. Tchernov, P. Ducos, C. Becker, A. Von Den Driesch, L. Martin, and A. Garrard 1999. Animal domestication in the southern Levant. Paléorient 25:63-80.

Ilan, O. and M. Sebbane 1989. Copper metallurgy, trade and the urbanization of Southern Canaan in the Chalcolithic and Early Bronze Age. In L'Urbanisation de la Palestine á l'Age du Bronze Ancien, edited by P. de Miroschedji, pp. 139-162. British Archaeological Reports International Series 527. BAR, Oxford.

Israeli, Y. and M. Tadmor 1986. Treasures of the Holy Land, Ancient Art from the Israel Museum. Metropolitan Museum of Art, New York.

Kempinski, A. 1978. Tel Masos. Its importance in relation to the settlement of the tribes of Israel in the Northern Negev. Expedition 20 (4):29-37.

Khalil, L. and K. Schmidt (ed.) 2009. Prehistoric 'Aqaba I. Orient-Archäologie. Band 23. Mari Leidorf, Rahden.

Kerner, S. 2009. The pottery of Tall Hujayrāt al-Ghuzlān 2000-2004. In Prehistoric 'Aqaba I, edited by L. Khalil and K. Schmidt, pp. 127-232. Orient-Archäologie. Band 23. Mari Leidorf, Rahden.

Köhler-Rollefson, I. 1993. Camels and Camel Pastoralism in Arabia. The Biblical Archaeologist 56:180-188.

Knabb, K.A., S.A. Rosen, S. Hermon, J. Vardi, L.K. Horwitz, and Y. Goren 2018. A Middle Timnian nomadic encampment on the Faynan-Beersheva Road: excavations and survey at Nahal Tsafit (late $5^{\text {th }} /$ arly 4 th millennium BCE). Bulletin of the American Schools for Oriental Research 380:27-60.

Kuijt, I. and N. Goring-Morris 2002. Foraging, farming, and social complexity in the Pre-Pottery Neolithic of the Southern Levant: a Review and Synthesis. Journal of World Prehistory 16:361-440. 
Levy, T.E. 2007. Journey to the Copper Age. Archaeology in the Holy Land. San Diego Museum of Man, San Diego.

Levy, T.E. and S. Shalev 1989. Prehistoric metalworking in the Southern Levant: archaeometallurgical and social perspectives. World Archaeology 20:352-372.

Levy, T.E., E. Ben-Yosef, and M. Najjar 2012. New perspectives on Iron Age copper production and society in the Faynan Region, Jordan. In Eastern Mediterranean Metallurgyand Metalwork in the Second Millennium BC., edited by V. Kassianidou and G. Papasavvas, pp. 197-214. Oxbow, Oxford.

Marcus, J. 1998. The peaks and valleys of ancient states: an extension of the dynamic model. In Archaic States, edited by G.M. Feinman and J. Marcus, pp. 59-94. School of American Research, Santa Fe.

Meshel, A. and Y. Tsafrir 1975. The Nabatean Road from Avdat to Sha'ar Ramon. Palestine Exploration Quarterly 107:3-21.

Milevski, I. 2013.The transition from the Chalcolithic to the Early Bronze Age of the Southern Levant in socio-economic context. Paléorient 39:193-208.

Müller-Neuhof, B. 2013. Southwest Asian Late Chalcolithic/ Early Bronze Age demand for "big-tools": specialized flint exploitation beyond the fringes of settled regions. Lithic Technology 38:220-236.

Ngendello, A.M. and W.C.S. Heemskerk 2004. Pack donkeys, bicycles, and carts: a case study from Sukumaland in NorthWest Tanzania. In Donkeys, People and Development: A Resource Book of the Animal Traction Network for Eastern and Southern Africa, edited by P. Starkey and D. Fielding, pp. 122-126. ACP-EU Technical Centre for Agricultural and Rural Cooperation (CTA), Wageningen, Netherlands.

Oren, E.D. and I. Gilead 1981. Chalcolithic sites in northeastern Sinai. Tel Aviv 8:25-44.

Ovadia, E. 1992. The domestication of the ass and pack transport by animals: a case of technological change. In Pastoralism in the Levant: Archaeological Materials in Anthropological Perspectives, edited by O. Bar-Yosef and A.M. Khazanov, pp. 19-28. Prehistory Press, Madison.

Parkinson, W.A. (ed.) 2002. The Archaeology of Tribal Societies. International Monographs in Prehistory 15, Ann Arbor.

Politis, K.D. (ed.) 2007. The World of the Nabateans. Steiner, Stuttgart.

Pratico, G.D. 1985. Nelson Glueck's 1938-1940 excavations at Tell el-Kheleifeh: A reappraisal. Bulletin of the American Schools of Oriental Research 259:1-32.

Quintero, L., P. Wilke, and G. Rollefson 2002. From flint mine to fan scraper: the late prehistoric Jafr Industrial Complex. Bulletin of the American Schools of Oriental Research 327:1748.

Reese, D.S. 1995. Shells from the Wadi Hisma sites. In Prehistoric Cultural Ecology and Evolution, edited by D.O. Henry, pp. 385-390. Plenum, New York.

Rosen, S.A. 1983. The tabular scraper trade: a model for material culture dispersion. Bulletin of the American Schools for Oriental Research 249:79-86.

Rosen, S.A. 1987. Demographic trends in the Negev Highlands: preliminary results from the emergency survey. Bulletin of the American Schools for Oriental Research 266:45-58.
Rosen, S.A. 2017a. Revolutions in the Desert: The Rise of Mobile Pastoral Societies in the Negev and the Arid Zones of the Southern Levant. Routledge, New York.

Rosen, S.A. 2017b. Basic instabilities: climate and culture in the Negev over the long term. Geoarchaeology 32:6-22.

Rossel, S., F. Marshall, J. Peters, T. Pilgram, M.D. Adams, and D. O'connor 2008. Domestication of the donkey: timing, processes, and indicators. Proceedings of the National Academy of Sciences 105 (10):3715-3720.

Rothenberg, B. and J. Glass. 1992. The beginnings and development of early metallurgy and the settlement and chronology of the Western Arabah from the Chalcolithic Period to the Early Bronze IV. Levant 24:141-57.

Rowan, Y.M. 1998. Ancient Distribution and Deposition of Prestige Objects: Basalt Vessels during Late Prehistory in the Southern Levant. Unpublished doctoral dissertation, University of Texas, Austin.

Saidel, B. 2002. Pot luck? Variation and function in the ceramic assemblages of pre-camel pastoralists in the Negev Highlands, Israel. Journal of the Israel Prehistoric Society 32:175-196.

Sapir-Hen, L. and E. Ben-Yosef 2013. The introduction of domestic camels to the Southern Levant: evidence from the Aravah Valley. Tel Aviv 40:277-285.

Schwimmer, L. 2016. Rock art survey in the Central Negev. Paper presented at Researches on Rock Art in the Central Negev, Sede Boqer, Nov. 25, 2016. Center for Negev Rock Art.

Segal, I. and I. Roman 1999. Chemical and metallurgical studies of copper ingots from Horbat 'En Ziq and Horbat Be'er Resisim. In Early Settlement in the Negev Highlands, edited by R. Cohen, pp. 22-37.-1. Israel Antiquities Reports 6, Jerusalem.

Shugar, A.N. 2001. Archaeolometallurgical Investigation of the Chalcolithic Site of Abu Matar, Israel: A reassessment of Technology and Its Implications for the Ghassulian Culture. Unpublished doctoral dissertation, Institute of Archaeology, University College, London.

Shamir, O. and S.A. Rosen 2015. Early Bronze Age textiles from the Ramon I Rock Shelter in the Central Negev. Israel Exploration Journal 65:129-139.

Simmons, A.H. 1981. A paleosubsistence model for Early Neolithic Occupation of the Western Negev Desert. Bulletin of the American Schools of Oriental Research 242:31-49.

Simmons, A.H. 2007. The Neolithic Revolution in the Near East. University of Arizona, Tucson.

Van Den Brink, E.C.M., L.K. Horwitz, H. Khalaily, N. Liphschitz, H.K. Mienis, and Y. Naggar 2004. A Chalcolithic dwelling and burial cave at Horvat Castra. Israel Exploration Journal 54:129-153.

Wapnish, P. 1981. Camel caravans and camel pastoralists at Tell Jemmeh. Journal of the Ancient Near Eastern Society of Columbia University 13:101-121.

Wayne, A.M. and W. Violet 2012. Trade and traders of Mesopotamian Ur. Proceedings of ASBBS (American Society of Business and Behavioral Sciences) 19:12-17.

Weinstein-Evron, M., B. Lang, and S. Ilani 1999. Natufian trade/ exchange in basalt implements: evidence from northern Israel. Archaeometry 41:267-273.

Wiessner, P. 1983. Style and social information in Kalahari projectile points. American Antiquity 48:253-276. 
Wright, K.E. and A.N. Garrard. 2003 Social identities and the expansion of stone bead making in Neolithic Western Asia: new evidence from Jordan. Antiquity 77:267-284.

Yekutieli, Y., S. Shilstein, and S. Shalev 2005. 'En Yahav: a copper smelting site in the 'Arava. Bulletin of the American Schools of Oriental Research 340:1-21.
Zarins, J. 1978. The Camel in Ancient Arabia: A Further Note. Antiquity 52:44-46.

Zohary, M. 1953. Ecological studies in the vegetation of Near Eastern deserts III: Vegetation map of the central and southern Negev. Palestine Journal of Botany 6:27-36. 